\title{
Levinas and Løgstrup on the Phenomenology (and Metaphysics?) of Moral Agency
}

\author{
Irene McMullin
}

\begin{abstract}
:
Moral agency requires escaping the orbit of one's self-concern. Both Levinas and Løgstrup offer an account of what is involved in this kind of perspective shift. For Løgstrup, this requires a forgetting of the self via an immersion in the patterns of life that spontaneously foster the other person's welfare. For Levinas, it involves a transformation of the self towards responsibility for the other whose presence challenges the legitimacy of one's selfprioritization. Both accounts make use of hyperbole when characterizing the imperialism of first-person claims and the moral disruption and asymmetry necessary to overcome it. This paper argues that this hyperbole plays an important methodological role but must be understood as metaphysically neutral - a distinction that Levinas's philosophy more successfully maintains.
\end{abstract}

$* * *$

Moral agency requires escaping the orbit of one's self-concern. Both Levinas and Løgstrup offer an account of what is involved in this kind of perspective shift. For Løgstrup, this requires a forgetting of the self via an immersion in the patterns of life that spontaneously foster the other person's welfare. For Levinas, it involves a transformation of the self towards responsibility for the other whose presence challenges the legitimacy of one's selfprioritization. In what follows, I will argue that both accounts make use of hyperbole when characterizing the imperialism of first-person claims and the moral disruption and asymmetry necessary to overcome it. I will argue that this hyperbole plays an important methodological role but must be understood as metaphysically neutral - a distinction that Levinas's philosophy more successfully maintains. ${ }^{1}$ 


\section{Levinas}

Levinas was deeply influenced by Sartre in his acceptance of the idea that the experience of being seen by another person provides a sense of oneself that cannot be selfgenerated but is nevertheless recognized as genuinely revealing dimensions of the self that could not otherwise appear. ${ }^{2}$ Though Sartre interprets this dynamic as a sado-masochistic struggle for power, Levinas understands it in terms of the possibility of ethical transformation. In the face to face encounter, he argues, one experiences oneself as answerable to the other person in a way that challenges the simple unthinking narcissism of the solipsistic self. One's claim to be the sole arbiter of the meaning of the world - and the meaning of one's own agency within it - is called into question in such a way that one recognizes that satisfying first-person claims is only one possibility - a possibility that no longer carries a default legitimacy but rather introduces the question of justification. Being answerable for the self to others in this way is, for Levinas, the essence of moral agency. It is characterized by both a negative moment, in which one is called out of one's self-enclosure, and a corresponding positive moment, in which one desires to go to and welcome the other. Both elements comprise the moment of transformation from a perspective of self-interest to a perspective wherein altruism becomes a possibility; a shift from first-person interests to second-person responsibility.

According to Levinas, this shift cannot arise simply from experiencing limitations on one's power. Rather, the experience of oneself as contested - as being in question and hence called upon to provide justifiable answers - is not simply an experience of limitation but is ultimately "the attitude of a being that distrusts itself" (Levinas 2007, 82). Hence the secondperson claim experienced in the face-to-face encounter must be understood to pose a challenge to the presumption of legitimacy or entitlement at work in first-person claims - 
which arrogate to themselves a kind of normative monopoly. This is what Levinas means by the self's impulse to totalizing.

Levinas describes the other person in such an encounter in terms of the ostensibly contradictory concepts of vulnerability and authority. He does so in an attempt to characterize this experience of contestation - an experience in which I encounter a presence that challenges my totalizing, but not by way of a counterforce of power to power. Rather, in such an experience I am shown through the other's vulnerability that my power is greater than I had realized as I am able to wield it not solely for my own good but for the good of the other. By submitting me to a judgment that challenges the legitimacy of purely selfish exercises of power, the ethical encounter gives me a new perspective on how to use my power - including the possibility of caring for the suffering other instead of only for myself. On Levinas' account, then, exposure to a presence that cannot be contained by one's first-person project of preference-satisfaction but rather contests its presumption to totality is at the root of moral agency.

\section{From Levinas to Løgstrup}

A recurring objection to Levinas' account is that it relies on an extreme conception of the asymmetry between the moral agent and the "other" who calls her into question. Levinas famously speaks of the "infinity" of the other that takes one "hostage" in a relationship of answerability that only goes one way (Levinas 1999, 2007). He also rejects attempts to ground this capacity for moral challenge in any specific feature of the other person - with critics consequently arguing that his view collapses into an empty nominalism. Though Levinas' account of politics makes room for the equality and reciprocity that we typically associate with ethics, he denies their applicability to the ethical domain: the moral relationship cannot be understood as limited or reciprocal from within that moral stance. 
Indeed, we may say nothing about the 'other' at all. Many find this approach extreme: we do not typically experience other people as mysterious and inaccessible sources of moral claims that can in no way be understood as reciprocal. ${ }^{3}$

For this and other reasons some have turned instead to K.E. Løgstrup's work, in which, as in Levinas, the moral encounter is characterized by an asymmetrical prioritization of the other over the self: "everything I say and do in our mutual relationship must be said and done for his or her sake rather than for my own” $(1997,46)$. But Løgstrup's account may appear to be an improvement on Levinas' insofar as it appears to:

1) ground the ethical claim in the natural conditions of human life, and

2) avoid the hyperbole of the latter's view.

In what follows I will argue that this confidence is unfounded. Løgstrup's own account is equally hyperbolic in its characterization of the asymmetric moral claim ${ }^{4}$, and his attempt to ground the ethical demand in structures of 'life' raises serious difficulties. Making this case will require us to examine the relationship between Løgstrup's two criteria for the ethical demand - conditions of mutual vulnerability and the belief that life is a gift $(1997,123)$. The latter, I will argue, rests on problematic presuppositions that threaten Løgstrup's account with untenable commitments. We see this in particular in a related belief that Løgstrup takes to be essential to experiencing life as a gift: namely, the belief that the self is fundamentally evil. I will argue that Levinas' stronger commitment to phenomenology both rules out the problematic metaphysical claims on which Løgstrup's ontological ethics depends and helps explain the methodological function of Levinas' hyperbole. By emphasizing the phenomenological status of Levinas' claims, I suggest, we can avoid some of the difficulties that characterize Løgstrup's view - difficulties, I submit, that Løgstrup's own position could avoid if it were to embrace a more overtly phenomenological approach and renounce its pretentions to metaphysics. 


\section{Løgstrup}

According to Løgstrup, the ethical demand requires one to give the other person's well-being priority over one's own. This primal normative claim is universal and timeless, arising immediately from certain basic conditions of human life. Our obligation to help those in our power is rooted in the fact that absent such helping, human life would be damaged: "our life would wither away and become stunted" (1997, 8-9); it would be "destroyed" and "we would be done for" (2007, 128-9). Certain forms of interaction - which Løgstrup initially speaks of primarily in terms of trust but later expands under the heading "Sovereign Expressions of Life" (SEL) - are characterized as basic to the proper functioning of human life: "The normativity of this ethics is thus located here, in what it takes for our lives to go well given the kind of creatures we are" (Stern 2019, 199). ${ }^{5}$ Behaviours that violate the SEL, then, are to be viewed as "defective" or "deficient" forms of the healthy human animal's natural mode of interaction (Ibid 36). Because the goodness and bindingness of these modes of healthy interaction - their normative standing - is taken to be a real feature of the world, not an achievement of human or divine will, Løgstrup can be understood to endorse a kind of natural law view (Stern 2019). Finding ourselves in natural power relations that put others at our mercy, we are by that very fact given reason not to exploit those others, else human life as we know it be made impossible: "Through the trust which a person either shows or asks of another person he surrenders something of his life to that person. Therefore our existence demands of us that we protect the life of the person who has placed his trust in us" (Løgstrup 1997, 17). With these positions of vulnerability and power comes the basic ethical requirement that we not take advantage of people but rather grant their needs priority.

Løgstrup insists that while this life-enabling function may provide a justification for the SEL, this fact should not be operative on the motivational level. Instead we ought to act 
purely for the sake of alleviating the other's suffering, not in order to enable the proper functioning of human life's structures of interdependence $(2007,128)$. Helping others is the loving moral orientation that underwrites and pervades our everyday unthinking patterns of interaction. The SEL are non-demand-based altruistic modes of seeing, feeling, and doing that create and sustain our shared lives $(2007,152)$; they are forms of pre-theoretical otherorientedness in which we spontaneously prioritize the other's good.

In contrast to the philosophical tendency to emphasize rules, explicit intentions, and formal principles, Løgstrup insists that ethics is fundamentally about these immediate relationships of altruistic benevolence that undergird our shared lives $(2007,92)$. Only when the smooth communal togetherness characteristic of the SEL breaks down does the ethical demand appear as such. Otherwise, one is simply embodying spontaneous expressions of 'life' with no thought of anything except how best to help the other person. Hence Løgstrup defines the ethical demand as impossible to meet: what it is ultimately demanding is that it never should have shown up as a demand in the first place: "the demand demands that it be itself superfluous" $(2007,69)$. Exiting the spontaneous moral coping of the SEL - by failing to trust, forgive, show mercy, and genuinely speak to the other - is to have already failed morally, no matter what kind of dutiful moral behaviour one engages in after the fact.

Løgstrup rejects moral theories that overlook this point, criticizing approaches that ground morality in the quality of a person's will or character as opposed to her loving relationships with other people $(2007,78)$. The result of these approaches is an ersatz morality - a substitute for the real thing wherein people do what is right because of duty or an interest in cultivating their own character, not because of an immediate natural urge to help others thrive. Though this is clearly better than "brutality or indifference," Løgstrup writes, “it is inferior to the immediate realization of mercy's sovereign expression of life. Duty enters when I am trying to wriggle out of the situation" $(2007,76)$. Hence the moral ideal is 
the spontaneous fellow-feeling and mutual support embodied in the SEL. And while the justification for their moral normativity is their ability to enable human communal life, the motivational manifestation of this normativity ought to be a spontaneous desire to promote the life of this or that other person.

\section{Problems with the Sovereign Expressions of Life}

Though appealing, Løgstrup's account faces serious difficulties. We see this, for example, in its account of moral agency, wherein the agent is expected to be engaged in simple acts of unconflicted benevolence that are so immediate that no thought of the self can arise as a possible motivation at all or the moral status of the act is, for Løgstrup, completely destroyed:

$[B] y$ calling mercy spontaneous, we mean that acts of mercy are elicited solely by the condition or situation in which the other finds himself, without the merciful agent deriving any benefit from his deeds, not for himself nor for any third party or institution. Mercy is spontaneous because the least interruption, the least calculation, the least dilution of it in the service of something else destroys it entirely, indeed turns it into the opposite of what it is - namely, mercilessness. Spontaneity is not something of which there can be more or less; it must be all in all if the sovereign expression of life is to prevail at all. Its radicalness consists not in any masterly feat but simply in the fact that the least ulterior motive is excluded. $(2007,85)$

Løgstrup views those who challenge any such sharp egoism/altruism divide as moral Pharisees; the slightest contamination of the purity of one's other-directedness with self - or "third party" - directed ulterior motives eradicates an act's moral worth. 
But this would mean that morality is limited to rare, isolated, and relatively shortlived events of pure spontaneous benevolence. For most of us, the moral landscape is often experienced quite differently: it requires balancing the long and short-term needs of multiple agents across changing circumstances; distinguishing necessary from self-indulgent forms of self-care, typically without the luxury of self-transparency about one's motives. As such, much of our moral life is defined by (pretheoretical) negotiation, deliberation, and balancing of competing and often incompatible claims - it is not typically an immediate and unthinking benevolence in which no concern for the self or third parties can be present at all. ${ }^{6}$

Even if we were to grant that such a state of radical, unconflicted, and unthinking benevolence is the ideal - an ideal that sometimes comes into view in certain benevolent encounters - one wonders whether Løgstrup can account for the possibility of moral agency short of this ideal. As we have seen, Løgstrup believes that certain conditions can involve completely prioritizing concern for the other person because 'life' takes over and negates or eradicates any competing concern for the self. As we will see below, there are worries here about the extent to which this can be understood as something attributable to the moral agent herself. And, short of this kind of immediate and completely selfless love for the other person, is there any room on Løgstrup's account for altruistic motivation?

We have seen that Løgstrup rejects the idea that virtue or duty could count as genuinely moral motivation insofar as it is driven by concern for one's status as virtuous or dutiful. Hence some other motivational structure must be operative if it is to be possible for the agent to break out of self-concern to manifest benevolence and to protect against sliding back into self-concern after having engaged in instances of the SEL. Løgstrup explains this possibility by way of the second condition that he stipulates - what he calls "a particular understanding of life" $(1997,116)$ - namely, the belief that life is a gift: 
[T]he demand which makes void protest from the viewpoint of reciprocity does not arise exclusively from the fact that the one person is delivered over to the other. This demand makes sense only on the presupposition that the person to whom the demand is addressed possesses nothing which he or she has not received as a gift. $(1997,116)$

In other words, moral agency - especially in conditions that fall short of completely selfless loving benevolence - requires both conditions of dependence and that people conceive of their entire life and its capacities for goodness as a gift. Such a belief need not and typically is not present as an occurrent propositional attitude; rather, an agent's acceptance of this belief can be (and typically is) entirely practical:

[This acceptance is] determined only by the manner in which he or she actually lives in this involvement with others. If he or she uses the involvement as an occasion for taking care of the other person's life, it is evident that in faith he or she accepts his or her own life as an ongoing gift. $(1997,123)$

In this emphasis on the gift status of life, we can see further evidence of the ontological optimism of Løgstrup's natural law orientation; namely, in his tendency to treat life as if it were equivalent to flourishing. As Stern characterizes his view: "unless trust, compassion, openness of speech, and so on were the norm, then human life itself would no longer persist in the form it does given our nature as interdependent creatures, which is what makes these structures inherent to life itself, thereby constituting its goodness" $(2019,283)$. But one might object that unless resentment, greed, betrayal and so on were the norm, human life itself would also no longer persist in the form it does given our nature as creatures bent on selfpromotion. Since these too are structures inherent in life itself, they thereby constitute its 
badness. Human life is regularly characterized by exploitation and instrumentalization. Hence we can note with interest what Nietzsche would say about the highly moralized conception of 'life' with which Løgstrup operates - a conception sharply at odds with the version of life that is red in tooth and claw. ${ }^{7}$

In response, Løgstrup might argue that one must merely be able to experience good aspects of human life as good to be capable of experiencing one's life as a gift. Doing so involves both being grateful for these good things and recognizing that we ourselves are not completely responsible for them: "we find these things given to us by the possibilities that life itself offers" (Stern 2019, 74). But Løgstrup insists that belief that life is a gift requires more than this: if one recognizes this fact and experiences this gratitude one will thereby of necessity also recognize that one:

...has no basis in their existence on which to make a counterdemand to another human being. In view of the fact that what a human being owns is something they have received, no counterclaim can be issued. The individual is a debtor, not by first committing some wrong, but simply because they exist and have received their life. $(1997,116)$

Hence the key idea behind 'life is a gift' is that the good (aspects) of life are experienced as a) things for which we are indebted and hence b) that we have no right to think of those goods as things to which they have a greater claim then the other person who could be helped by them.

But why shouldn't one just enjoy the goods one has been 'gifted'? Why does the mere fact that I didn't create the goods I enjoy mean that I must use those goods to help others and make no claim on those others to help me in turn? How, in other words, can the demand 
show up as a claim that falls outside the economy of exchange? Løgstrup's answer turns on the question of sovereignty: one can either experience oneself as sovereign over one's life and thus as having the authority to make demands on one's own behalf - or one can experience life itself as sovereign - and therefore not as something for which one has any right to take credit or claim reciprocal benefit from other people $(2007,116)$. The latter is the appropriate stance, he argues, and is what the belief that life is a gift amounts to.

In contrast to my reading here, however, one might object that in fact all that the 'life is a gift' idea is doing is countering the tendency to make counterdemands. In other words, ethical concern itself arises simply from the fact of the other's vulnerability and understanding life as a gift is not necessary for experiencing the demand but only for blocking the tendency to think in reciprocal terms and demand something back in kind. Hence on this reading, the 'life is a gift' component of Løgstrup's view is less central than I have suggested.

But Løgstrup argues that merely caring for the vulnerable other - i.e., responding to the demand in a way that does not involving thinking of how doing so will benefit you requires you to understand life as an ongoing gift: "If he or she uses the involvement as an occasion for taking care of the other person's life, it is evident that in faith he or she accepts his or her own life as an ongoing gift" $(1997,123)$. Similarly, he says: "the demand says to us that precisely because our life was given to us and since of ourselves we therefore are nothing and possess nothing, we are therefore to take care of the other person's life" $(2007,127)$.

In response, one might object that Løgstrup does not stipulate the importance of life being a gift until he raises the issue of reciprocity in chapter 6 of The Ethical Demand - and as such these claims may be read as specific to the issue of neutralizing counterdemands (Stern 2019, 75 note 13; 156-7). As he says in Beyond the Ethical Demand: 
First I analyse how the life of one person is interwoven with the life of another, and from this I deduce the content of the demand, which has to do with taking care of the life of the other person that has been delivered up to us. Some way into the book I make it clear that the onesidedness of the demand cannot be deduced in this way, but presupposes that life has been given to the individual person. $(2007,10)$

Hence one might suggest that life delivers the other to my power such that I'm required to care for her, but the one-sidedness of this demand is a further aspect that arises from the belief that life is a gift - an aspect that cannot be deduced from the mere fact of our interwoven state. So, one might argue, Løgstrup does not characterize the belief that life is a gift as constitutive of the demand itself, but only as a tool for responding to it appropriately.

But does this track the way that Løgstrup characterizes the experience of the demand throughout the book? Recall that the ethical demand stipulates not simply that I must not exploit the other person, but rather that I must actively help her, often at my own expense, by using the goods life has given me not for my own benefit but for hers. Hence the issue regarding one-sidedness isn't just that I cannot claim recompense once I have used the goods of life for the other person's sake; the issue is being able to see my goods as things I must give the other person in the first place. The one-sidedness of the demand is about the possibility of experiencing a genuinely second-personal motivation that isn't merely selfinterest in disguise but is rather a radical reversal of our natural valuational structure such that the other person's life is taken as having more value than one's own (Løgstrup 1997, 115). Hence talk of one-sidedness for Løgstrup is not (just) about blocking a certain kind of move in an iterative morality game - a move necessary after the demand has registered; rather, it's about the nature of the demand itself as being a radical inversion of the normative landscape. While Løgstrup argues that the demand arises from the fact of our mutual dependence, then, 
the nature of its asymmetrical bindingness is founded on the understanding of life as a gift. It is in terms of this understanding that "the demand stands or falls"; "The demand that he or she take care of the other person's life is rooted in the very fact of his or her indebtedness for all the different potentialities he or she has him or herself received" $(1997,116)$. Hence the argument is that this asymmetry is not something separate from or secondary to the demand itself, but intrinsic to its structure - else the demand would be experienced as simply another move in an economy of competing interests. Instead, from the beginning Løgstrup characterizes the demand itself as "silent, radical, one-sided, and impossible" $(1997,7)$ - and argues that the one-sidedness component of the demand is only experienceable as such on the basis of the understanding of life as a gift.

On this view the goods of life and the help I can provide the other person with these goods are not my own in the sense of being something for which I can legitimately take credit or claim ownership. Since I am not the source of love and trust in the universe but simply a participant in those things, I should not expect or demand anything in return for the ways I might happen to manifest them to others: "the demand says to us that precisely because our life was given to us and since of ourselves we therefore are nothing and possess nothing, we are therefore to take care of the other person's life" $(2007,127)$.

Re-framing my life and abilities as mere gifts over which I have no legitimate claim to priority of care or use - since I am "nothing and possess nothing" - enables the secondperson recognition of the other's claim to take priority over any first-person claims I might be experiencing. ${ }^{8}$ Hence the other person's dependence on me, when coupled with this belief that life is a gift, enables me to place the other person's needs first.

Note how this view presupposes a logic of fairness and reciprocity such that I don't deserve to keep or ask for goods in my life if I didn't create them. It relies, in other words, on certain presuppositions about the connections between concepts like causal source, desert, 
and just claim. Hence the worry arises that this view is assuming the very moral logic that it is purporting to explain. Why should the mere fact of dependency on life - the fact that I did not create all the good things that I enjoy - interrupt or challenge the ego's belief that it deserves all good things, even if it does undermine its ability to have all good things? Recall Levinas' argument: experiences of the limits of one's power are insufficient for producing a challenge to the legitimacy of one's power. The mere fact that I didn't create myself and am not omnipotent does not produce a self-relation wherein I question my right to do what I please within the constraints of those givens such that the one-sidedness of the demand could manifest as such, requiring me to place the other's needs above my own. In other words, the 'life is a gift' claim cannot function simply as an experience of the goodness of life or the limits of one's power if it is to ground the normative shift to selflessness that Løgstrup requires. ${ }^{9}$ Rather, it requires a refutation of the legitimacy of one's claim to the goods of life.

This, coupled with Løgstrup’s personal and philosophical history, prompts some to read the idea of the "gift" in terms of a creator God to whom our lives ultimately belong. On this reading one can see how the agent might be challenged in the requisite way - namely, the divine other's judgment might disrupt our complacent sense of default legitimacy comparable to the way that Levinas describes in his account of the radically asymmetrical ethical relation. The presumption that one deserves all goods might be called into question through the presence of one who challenges that sense of entitlement. But such a reading is at odds with the secular ethics that many of us - Løgstrup included, allegedly - wish to produce. ${ }^{10}$ But it's not clear where this sense that one may not deserve life's goods is meant to come from if the notion of the 'gift' of life is stripped of its theological underpinnings.

\section{Evil and Asymmetry}

It is for this reason, I contend, that Løgstrup characterizes the idea of life being a gift 
in terms of an experience of oneself as worthless. Recall: "we are nothing." Indeed, he introduces the view that we must view ourselves as fundamentally evil if we are to properly understand our moral condition $(1997,140)$. Thus Løgstrup's rosy conception of a naturally morally ordered universe comes into sharp relief against the evil status of individual human beings; a view that has been described as ontological optimism combined with anthropological pessimism (Rabjerg 2017, 102-3). The explanation for this natural human 'evil' appears to be our inwardness - the Lutheran conception of 'incurvatus in se' - whereby we only think of ourselves, not the needs of others. In other words, this moment of unnatural "wickedness" within the natural goodness of life appears to be a result of our self-awareness - "attempts to shore up the selfhood which arises with our reflective capacities" - and the resulting natural disposition toward "anxiety and need for control" rooted in the "peculiarly human sense of the self and its fragility" (Stern 2019, 108, 282). ${ }^{11}$ Hence Løgstrup characterizes our 'evil' in terms of being creatures who are aware of their own vulnerability and who prioritize this at the expense of serving the other person's vulnerability. Such awareness and concern for vulnerability is the meaning of goodness when it's the other person's vulnerability at stake; it's the definition of evil if it's one's own. ${ }^{12}$

But why should responding to the other person's vulnerability have such a radically different moral status than caring for one's own? The suggestion seems to be that if we only care about our own vulnerability then all of the communal dimensions of human flourishing would be ruled out. Of course, if we only cared about the other person and took no notice of our own needs then life as we know it would also collapse. Indeed, the individual's responsibility to take care of her own life forms the basis of Løgstrup's argument against paternalism and encroachment; as Stern puts it: "while their dependence on us gives us responsibility over others, individuals also have responsibility for their own lives, which we cannot then take away in responding to their needs" $(2019,43)$. It might be wondered, 
however, why the other person's responsibility for her own life is not taken to be a manifestation of her fundamental 'wickedness' and as such to have no moral standing. Why is this 'evil' an attribute that only applies to $m e$ ?

In keeping with this asymmetry, Løgstrup specifies that it is only the positive or 'lifeaffirming' elements of my selfhood - my capacity for enacting love, trust, and mercy in my life - for which I can take no credit. Any disruptions to those sovereign expressions of life, however, are to be attributed to the wickedness of the self. But why should we believe that the self is responsible for all its evil actions but none of its good ones? Løgstrup himself recognizes that if we were to claim that we are the cause of neither our good nor our evil actions we would be in danger of completely dissolving the self qua locus of ethical responsibility - a conclusion he wants to resist:

[T]he opposite of what we have just said about trust and love is true with respect to reservation and selfishness. I am myself the cause of my reservation and selfishness; they are indeed my own achievements...We can insist that I cannot help my reservation and selfishness, because this is the way I was created; and since I did not create myself I cannot accept the responsibility or the blame for how I am. But the result of such abstract argumentation is that 'my' thoughts, 'my' actions, 'my' feelings are no longer mine; they could be mine only if I could take over my own life, so to speak, through being the cause of and assuming the responsibility for who I am and what I do. In short, I become nothing. $(1997,139)$

Hence Løgstrup appears to be faced with two choices: he can associate evil with selfhood and goodness with the a-subjective forces of life itself, or he can hold that there is no such thing as a responsible self at all. He is limited to these two options because he has ruled out the 
idea that the self can be responsible for the goodness in which it participates - the view that Levinas adopts via the idea of the ethical transformation of the self toward responsibility. But this approach is closed to Løgstrup because he has insisted that all trace of the self must be annihilated in the service of the other if there is to be any moral worth in an action at all.

But if it's 'life' acting in all cases of goodness, not the self, how is it to be understood as 'my' ethical responsiveness? Indeed, hasn't the self been defined as irredeemably selfish in a way that would make the good work of 'life' completely unintelligible to any self being overtaken by it? Doesn't this rule out the kind of interpretation and specification work that are a necessary feature of moral agency, even for Løgstrup? If this is so, Løgstrup can't account for the possibility of such moral agency; he simply advocates for the eradication of a self that is deemed incapable of it. He has defined the self as normatively corrupt in a way that would seem to prevent genuine access to care for the other, except insofar as the self is replaced or colonized by anonymous forces of 'life'. But what is the relationship between 'self' and 'life' such that the former could be both irredeemably selfish and yet a willing and responsible vehicle for the anti-selfish forces of 'life'?

In Levinas's philosophy we see quite a different conception of the self-life relationship. There lack of selfhood is characterized in terms of the undifferentiated 'il y a' the 'there is' - his name for the pure givenness of anonymous life in which there is no differentiation, no separation into an 'I'. In this state of pure being there are no beginnings or endings, no distinctions within the sheer plenitude of existence. In contrast to this totalizing anonymous life, the self is a kind of upsurge of interiority, a resistance and movement inward. Levinas makes use of a number of pre-reflective experiences such as insomnia and suffering to help us conceptualize this "undifferentiated life" dimension of possible experience $(1987,48) .{ }^{13}$ Hence unlike Løgstrup, Levinas resists the suggestion that the eradication of self and the return to such anonymous life could account for the ethical 
encounter. On the contrary, it would remove its condition of possibility: the self in whom moral concern or responsibility could arise. Characterizing 'life' as the vehicle of morality whether one adopts a Løgstrupian or Levinasian model - is at odds with the possibility of responsible moral agency.

In contrast to Løgstrup's view, then, Levinas' approach does not require one to see one's own self-interested preferences as evil, but rather as questionable insofar as they stake a claim to the totality of the normative sphere. What this involves is a transformation of the self - a process of becoming that is not a return to the natural substratum of life but is, rather, a transition in consciousness from the natural/instinctual narcissism of an animal way of grasping the world to the fully human terrain of normative consciousness. It is for this reason, Levinas argues, that we need to be careful not to moralise the state prior to the ethical transformation. Prior to the moral encounter that initiates second-person concern for the other we are neither good nor evil since that normative distinction is not yet available. The issue isn't how to overpower a self that is evil, but rather to open the self up to experiencing normative claims that come from outside its orbit of self-enclosure.

To be sure, Løgstrup himself wants to resist these difficulties, later suggesting that acting on the SEL isn't simply a loss or forgetting of self but rather a way in which to realize our 'true' self: "a person becomes their true self, and concretely so, by realizing themselves in the sovereign expressions of life and identifying themselves with them" $(2007,54)$ and "The expressions of life cannot be applied, but can only be realized, as I realize myself in them" $(2007,53)$. But it's not clear that this approach is available to him. Why is someone who is fundamentally evil her 'true self' insofar as she participates in the goodness of the SEL $?^{14}$ The inconsistency of this view with earlier claims about the self's fundamentally evil nature is evident in Rabjerg's claim that "The sovereignty of the expression of life creates the possibility of actualizing the original self that is otherwise submerged beneath self-absorption 
and inturnedness" $(2014,130)$. Here the self is being characterized as fundamentally or originally good - but as having simply fallen away or forgotten this original state of goodness. But if this is the case - that the self is in fact good but forgets or conceals that goodness from itself - why does Løgstrup insist that we attribute only evil to ourselves and all goodness to life itself?

\section{Løgstrup: Metaphysician or Phenomenologist?}

These issues raise important questions about the register in which Løgstrup is writing. I want to suggest that despite all evidence to the contrary, Løgstrup is not - or better, should not be - understood as making metaphysical claims about the grim realities of human nature. Rather, I want to suggest that the best way to understand Løgstrup's account - whether he himself fully realized it or not - is as a phenomenological description of what it is like to experience oneself as being in the grip of a moral relationship. Read this way, I contend, he is not asserting that we are evil (or indeed that life is a gift or is the source of all goodness). Rather, his view is one wherein moral agency requires us to think of ourselves as evil, to interpret life as a gift that we don't deserve, if we are to be able to shift away from being so preoccupied with our own needs that we don't see or care about the vulnerability of others. In other words, one possible way to understand Løgstrup's insistence that we are fundamentally 'evil' is in terms of a rhetorical move aimed at capturing - and perhaps enabling - the lived moral experience. On this reading, to be a moral agent is to be either swept along in what feels like spontaneous helping - and which involves an implicit sense of oneself as having no right to those goods - or to be in the grip of a guilty sense that one ought to be helping but that one is too evil to do the thing one recognizes one ought to do. In the latter case one's only recourse is to try to surrender to forces conceptualized as originating from an external source - life - whose goodness has not been so corrupted. Hence it is a feature of moral 
agency that we implicitly or explicitly think of or take ourselves as worthless and life as a good we don't deserve. It is, we might say, the mode of self-manifestation operative in the second-person orientation in which we feel claimed by the other's need. But this practical self-conception has no metaphysical implications. The ethical experience involves firstperson self-attributions of evil that do not need to be grounded in any metaphysical truths about the world - though believing that they are may help motivate the individual agent to engage in such self-attribution. But as we discussed above, the belief that life is a gift (and hence that I am evil) is not an occurrent proposition but rather a mode of engaging with the world - namely, one wherein I treat myself or conceive of myself as evil or worthless. Hence Løgstrup's talk of our fundamental evil is not best understood as a metaphysical posit about human nature, but rather as a phenomenological description of a feature of the second-person encounter: the self-conception operative in radical selflessness.

This self-attribution of evil and worthlessness to the self cannot - or cannot entirely ${ }^{15}$ - be something that the agent deliberately does, since that would make her responsible for her entry into the second-person perspective of love. Responsibility for this moral transformation is something that both Løgstrup and Levinas wish to deny - insisting that inauguration into the second-person stance is triggered by the presence of the other person, not by an act of will on the part of the agent. What a phenomenological analysis of the moral experience reveals, however, is that it involves both an experience of the other as a vulnerable presence to or for which I am answerable, and a certain kind of experience of the self - as evil (Løgstrup) or as called into question (Levinas). In what follows, I will show why I take Levinas's phenomenological description of moral agency to be more accurate. Before doing so, however, I wish to briefly consider the legitimacy of my suggestion that Løgstrup's claims about human agency should be read as phenomenological description, not metaphysical posit. 
Løgstrup himself appears to be quite conflicted on the degree to which his account commits him to any such metaphysical claims. At times 'life is a gift' is simply characterized as a mode of engagement or experience - an 'understanding of life' that enables or underwrites other kinds of lived experience and that need not commit one to any metaphysical claims about whether this understanding tracks a reality beyond the interpretation itself. On this view his claims about our culpability and evil are simply specifying the self-understanding operative in well-functioning moral agency. But there is also a good deal of evidence in support of the view that Løgstrup himself did not understand his project this way:

to use the classical philosophical terminology: The one-sided demand contains an ontology, a fundamental and constitutive determination of being, namely, that human existence and the world that goes with it have been given to human beings. (Løgstrup $1997,171$ note 2$)^{16}$

Insofar as "containing an ontology" means "posits the truth of a certain configuration of reality' then Løgstrup's 'phenomenology' bears little resemblance to that methodology as it is typically understood. In Løgstrup's case 'phenomenology' appears to be mainly operative in a rejection of the scientism of his day in favour of an analysis of ordinary experience. ${ }^{17} \mathrm{He}$ does not seem much interested in the phenomenological method as Husserl envisaged it namely, as a method dedicated to uncovering the structure of lived meaningful experience, having bracketed all metaphysical commitments regarding the nature of reality as such including those metaphysical commitments operative in the everyday ways we interpret the world. But if "containing an ontology" means that a certain structure of experiencing including the tendency to hold certain metaphysical views - underwrites the possibility of 
moral agency, then he is much closer to phenomenology - and Levinas - than he initially appears.

Evidence that Løgstrup is indeed describing the self-conception necessary for moral agency (thinking of ourselves as evil) - and not positing metaphysical facts (we are evil) can also be found in his claim that we must think of the selfishness of our nature as being our own fault. On a phenomenological reading, viewing ourselves as guilty for our own selfish nature is a necessary condition for experiencing the demand as binding without its unfulfillability undermining our sense of its legitimacy (Løgstrup 1997, 166). Løgstrup has interesting (and at times bizarre) things to say about how we must "anthropomorphize" the demand in order to be able to think of ourselves as guilty for something that we are by nature:

Previously, when it was made clear that we can only talk in anthropomorphic terms about existence and its demand on us, it was stated that the reason for this is that existence must defend itself against our observation that due to our nature it is unfulfillable. Now it can be added that existence together with its demand must defend itself against our statement of the unfulfillability of its demand, in such a way that it transforms our observation into an acceptance of the unfulfillability as being our fault. We can remain in the contradiction only by taking a position with respect to it. $(1997,167)$

The idea seems to be that a situation in which we are responsible for meeting a demand that our nature makes it impossible for us to meet can only be made coherent by 'taking a position' according to which we think of ourselves as responsible for this very nature ${ }^{18}$ perhaps cultivating this guilt by conceiving of existence or life itself as a wronged party. ${ }^{19}$ 
This idea that we're 'taking a position' with regard to our own culpability undermines the view that Løgstrup is (or ought to be) making a metaphysical claim when he characterizes all humans as fundamentally evil. ${ }^{20}$ Instead it supports the suggestion that he is in fact describing or indeed promoting the self-understandings that must be in place for love and its derivative form - the demand - to claim us. Hence I want to suggest that Løgstrup's 'self is evil, life is good' mantra should not be understood as a claim about our nature, but a claim about a necessary understanding of our nature insofar as moral agency is to be possible:

we cannot use this unfulfillability to claim that the demand no longer applies to us: for, responsibility for facing this unfulfillable demand, and thus this 'contradiction' within which we are caught, is something we must attribute to ourselves as stemming from our self-centred wickedness, while any goodness must be attributed to life and not ourselves. (Stern 2019, 85 emphasis mine)

This 'self-attribution' can occur either at the level of metaphysical speculation about what human nature is like in reality - namely, evil - or it can occur at the level of existential selfunderstanding; the agent's practical orientation to the world. Namely, in terms of how we need to think of ourselves as evil if the de-legitimation of our own preferences - and hence altruistic motivation - is to be possible. I submit that the best way to make sense of Løgstrup's view is in this latter, more robustly phenomenological vein - though it is unlikely that this is what he took himself to be doing. In other words, I'm arguing for an interpretation of Løgstrup that downplays his metaphysics and plays up his phenomenology - an interpretation that is, I believe, more true to the phenomena and avoids other philosophical difficulties. 
In contrast to Løgstrup's ambivalence on these methodological points, I have been suggesting that Levinas be read as having adopted a more robustly phenomenological approach. He begins Totality and Infinity with the claim that "the presentation and development of the notions employed owe everything to the phenomenological method" $(2007,28)$. Though there are those who resist this reading (see note 1 above) I contend that Levinas' metaphysical-sounding claims about 'infinity' and 'alterity' are - as with Løgstrup's - also best understood as descriptions of structures of first-person experience, not as metaphysical claims about the nature of reality as such. In other words, these hyperbolic descriptors should be read as rhetorical devices used to capture the nature of lived moral experience. In what follows, I will argue that Levinas' approach to doing so better describes the lived experience of moral agency than Løgstrup's, since it substitutes questionability and responsibility for evil and selflessness.

\section{Ethics As First Philosophy}

If Levinas does not think that the ethical encounter demands a conception of oneself as 'evil,' what does he think it involves? The language he uses to describe the ethical encounter might suggest that he is committed to what might be understood as a command view of morality. In contrast, Stern argues that Løgstrup's view rests on a strong distinction between moral 'demands' and moral 'commands.' In the former case the nature of the authority at work in the claim is the content of the claim itself. Namely, the vulnerability of the other's life. In the latter case, it is the other person's authoritative status that underwrites the moral force of the claim, not the content of the claim itself. Hence one could argue that Løgstrup's natural law approach and its commitment to the goodness of human life puts him in the former camp, while Levinas' emphasis on the commanding authority of the other person makes him a 
moral command theorist - with the other person's authority being the foundation of a moral claim's legitimacy $(2019,270-87)$.

We have already seen that Løgstrup's view involves more than just the experienced vulnerability of the other person; it also involves an understanding of oneself as worthless and indebted for the gifts of life - in short, it requires experiencing life itself as having a certain kind of normative authority in order for the shift to second-person concern to be possible. This complicates the neat demand/command distinction even in Løgstrup's philosophy. We also ought to resist this interpretation of Levinas' view, however, and for two reasons. The first reason can be captured under Levinas' slogan 'ethics is first philosophy.' What Levinas means by this is that the practice of philosophy - which is defined by the work of categorization, conceptualization, and evidence-based justification and legitimation procedures - is only possible on the back of encounters with others who pull me out of my self-enclosure and make the activities of 'answering for' (justification) and putting in general (conceptualization) possible in the first place. Hence the ethical relation doesn't make being possible - 'ontology' in that sense; rather, it makes the conceptual project of explanation and justification possible - 'ontology' in the sense of a human practice of conceptualizing and evidencing the nature of reality. Being answerable to the other - being called on to respond is a condition for the possibility of discourse and the concepts by which we put the world in common such that it can be shared in discourse, including philosophical discourse.

Hence for Levinas any attempt to legitimate or justify the ethical encounter - by grounding it in the goodness of life itself, for example - fails to acknowledge that the activity of grounding is itself only made possible by this very encounter. One can attempt to stipulate the necessary and sufficient conditions that make it possible for others to show up for us such that we are called to answerability, with its attendant practices of justification and categorization. Certainly we - including Levinas - do this. But Levinas' purpose is to remind 
us that in doing so we are presupposing the fundamental condition that allows us to engage in this kind of investigation to begin with - namely, the second-person orientation to the other as one to whom I am called to answer. Hence discussion of what categories allow us to distinguish one 'other' from another 'other' - or what justifies their claim on us - can only take place outside of the parameters of the second-person perspective in which such others show up as claimants, and it does so using the tools whose condition of possibility it purports to explain. By asking about the justification for the experience of answerability we are exiting the second-person stance to consider others in terms of the attributes that may or may not enable them to call us to account in this way. Levinas' point about 'ethics as first philosophy' is that this justificatory activity is derivative of the primal event of ethical encounter in which I realize that the world is not mine alone.

Hence questions about whether Levinas endorses a 'demand' or 'command' view insofar as these are questions about the source of justification for the experience of ethical claim are in a sense beside the point for Levinas.

Finally...it could be argued that as we have seen, Levinas's conception of 'ethics as first philosophy' commits him to taking this command view, as only then will normativity be grounded in something other than being, and stem instead from the normative authority of the other through which our capacity to occupy a world is made possible at all. However, the difficulty for Levinas is to explain what makes the difference between this as an exercise of authority, rather than merely coercive force, if there is nothing about the other that makes their command legitimate; but if there is something about the other that does so, then that would seem to require us to attribute some sort of prior ontological status to the other, thus moderating the "ethics as first philosophy' claim. (Stern 2019, 287) 
But it is not that the other person's authority or destitution legitimates the demand that I go to her - rather, it is the experience of being called to go to the other that pulls me out of my selfabsorption and makes questions of legitimation possible for the first time. After the fact I may attribute to her some ontological status to try to explain how this event of normative transformation could have occurred - but insofar as I do so I am no longer occupying that ethical stance, but still making use of tools that are only possible on its basis.

Hence Levinas' use of normative talk to characterise that answerability should be read phenomenologically - namely, as descriptions intended to trigger in us recognition of what it is like to experience the ethical encounter, not as justifications for that experience. Levinas's characterizations of the other - in terms of suffering, height, authority, destitution, etc. - are all aimed at describing the experiential qualities of being in the grip of the second-person stance. They are not assertions about a metaphysical status. ${ }^{21}$ The face shows up for me as both 'lower' and 'higher' because these are modes that are incompatible with a stance of experienced equality between self and other: "the structure of this responsibility will show how the Other, in the face, challenges us from the greatest depth and the highest height - by

opening the very dimension of height." ${ }^{22}$ By 'opening the very dimension of height' Levinas means bringing the self out of an orientation in which all things are understood as being available for comparison and categorization - and into an experience of a presence that challenges this.

\section{Experiencing the Moral Presence of the Other}

This brings us to the other reason to reject the characterization of Levinas as a command theorist. As we have seen, Løgstrup's natural law account places the normative justification for the demand's bindingness on the fact that helping vulnerable others is a necessary 
condition for the possibility of flourishing life. And, according to Stern, the normative justification for the ethical encounter's bindingness on a Levinasian account is instead the other person's authority to make claims.

But this interpretation relies on a distinction at odds with Levinas's approach. On his view, the claim that one recognize the authority of the other person to make claims is in effect the content of the ethical demand. 'Demand' and 'command' accounts merge in his understanding of the face-to-face encounter because responding to the content of the demand - that I treat the other's claim as reason-giving - just is to see the other person as an authority capable of making claims on me. In the first-person perspective one operates with a fundamental orientation to the satisfaction of one's own projects and preferences. It is, as Levinas says, the conatus essendi of every being's struggle to be (Levinas 1999, 4). On the second-person stance, in contrast, one has been broken out of this focus on the self such that the other person's preferences and projects - her own struggle to be - is taken to have normative significance. She shows up, in other words, as the locus of a normative weight whose very presence challenges me to question the legitimacy of my own self-promotion. Moral agency depends on that pretention to totality being called into question by being exposed to sources of normative authority outside of the self. Hence experiencing the other person's authority as authority just is to acknowledge the truth of the fact that I am not the only source of normative authority. And, crucially, Levinas does not hold that the demand to be recognized as a source of normative legitimacy is something that the other person does. Instead the demand just is the experience of a presence that cannot be subsumed to my own normative perspective without remainder - and which thereby challenges my presumption to totality. In this event of challenge I am called upon to take the other's needs as having a certain kind of status: namely, as having a prima facie claim on what I ought to do. This presence that triggers the event of transformation - which Levinas calls 'face' or 'illeity' - is 
not meant to specify a metaphysical condition that justifies the moral claim: rather, these are simply evocative names for the experience of a resistance to my totalizing - a resistance that is not (necessarily) experienced as something that the other person does.

Of course, one might object that Levinas describes the relationship to the other person as one in which I am indeed subjected to an explicit command - namely, 'thou shalt not kill':

But the relation to the face is straightaway ethical. The face is what one cannot kill, or at least it is that whose meaning consists in saying: 'thou shalt not kill'. Murder, it is true, is a banal fact: one can kill the Other; the ethical exigency is not an ontological necessity. The prohibition against killing does not render murder impossible, even if the authority of the prohibition is maintained in the bad conscience about the accomplished evil. $(1985,87)$

But note that it is not the other person who says 'thou shalt not kill'. Rather, the other person is defined by a mode of presence according to which that meaning is conveyed. The face is "that whose meaning consists in saying: "thou shalt not kill'."

But isn't this still a command? It might be taken as a kind of command insofar as it issues from some way in which the specific other person is given to me in experience - and not from an anonymous or general 'life itself'. In contrast, Løgstrup argues that though it is the individual other person whom I must love and assist, but it is nevertheless life making a claim on me. As Stern puts it: "the fact that we are not just required to do what the other person asks of us shows that we are responsible to life rather than to the other person" (2019, 189). But is this right? If I deny my child ice cream despite her obvious desire for it, it's not because I'm responsible to 'life' but rather because I am responsible to her - her understood as this specific potentially flourishing self, not understood simply in terms of whatever 
occurrent desire she happens to be in the grip of. As we have seen, (Stern’s) Løgstrup wishes to capture this sense of potential individual flourishing under the rubric of 'life itself' properly understood. ${ }^{23}$ Nevertheless, to speak of my obligation being to 'life itself' - as opposed to this person - decouples good states (flourishing life) from the individuals in whom they are to be realized (individual persons who might flourish) - with the consequence being that Løgstrup's view is opened up to objections of a kind raised against utilitarian maximizers. Namely, it's difficult to see why one shouldn't put one's resources into group X at the expense of group $\mathrm{Y}$ insofar as a greater number of life enhancement points could be achieved by throwing group Y under the bus. Stern recognizes this danger in his discussion of Darwall's critique of Løgstrup, in response to which he concludes that when others ignore their moral obligations, "this makes us victims of wrongdoing as individuals in a way that does not happen in the case of ignoring logical obligations, and thus bestows on us (and by extension those who act on our behalf) the authority to hold the wrongdoer to account, where no such authority exists when a logical requirement is ignored" (2019, 306 emphasis mine). But what is it about the individual qua individual - and not simply as an instantiation of 'life' - that is violated by the moral failure?

In response to such Levinas-style worries that responding to life involves subsuming the unique other person to a general category such that they become mere tokens of the valued type, Stern reminds us that Løgstrup himself introduces talk of the "singular universal" to try to avoid this objection:

He illustrates this idea by appeal to three examples: colour, species, and the expressions of life. Thus, redness might be present in my book, my pen, and my jumper, but for Løgstrup this redness is still singular and not general as it is one and the same in each of them but it just manifests itself in different places, while as a 
property it is dependent on there being individuals to be so manifest. A species like 'human being' is also present in a similar way in a variety of individuals, but unlike colour it is by being present in such a way that there are individuals, because how the same species is present can be differentiated enough to constitute an individual. (Stern $2019,280)$

Hence it is life as manifest in individuated form that in fact makes a claim on me, not 'life itself'. Nevertheless, Løgstrup insists that we must resist the conclusion that the other person therefore makes the claim, an insistence that turns on the moral logic of debt outline above. Namely, the one-sidedness of the claim would be annulled if it were to come from the other self, who is also a selfish moral failure and as such can't claim from me the acts of selfless beneficence that she herself would be unwilling to provide. Hence the one-sidedness and unfulfillability of the demand means that it can't be the other self to whom I am accountable, but only the other potentially flourishing life. If it were the former, Stern argues, I could lodge a counter-demand and view my own efforts as equally good at fulfilling the demand thereby getting me off the hook $(2019,125)$.

In this, then, it seems that Levinas and Løgstrup are in some agreement: the moral claim is not something that the other person does, but rather something that arises between self and other simply on the basis of the other's mode of manifestation. But they differ as to why this is the case: for Løgstrup, the evil of the other person's agency is at odds with the extent to which the demand claims me, and hence the demand is best understood as an obligation to the life in them. ${ }^{24}$ For Levinas, the other person's resistance to my conceptualizing and comprehension means that I cannot attribute the claim I experience in their presence to an act or feature of their agency. For Løgstrup the demand cannot be a 
function of the other's agency because that agency is corrupt; for Levinas it cannot because that agency is inaccessible, even in analogy with my own.

Of course, one might object that unless we take advantage of something like Løgstrup's notion of 'life' - even if in singular universal form - then Levinas's account

...collapses into a nominalism that is itself incoherent, as what is it that distinguishes one 'other' from another once all properties have been stripped away?...it would seem to deprive the I one encounters of any characteristics at all-in which case, it is hard to see what could differentiate one I from the next, in such a way as to give it the very uniqueness that Levinas emphasizes. (Stern 2019, 281)

But we have seen that for Levinas, occupying a stance wherein one compares multiple 'others' - distinguishing and differentiating them - is to have exited the second-person perspective of the ethical encounter and to have entered the third-person perspective characteristic of what Levinas calls justice. On this stance, others are experienced in terms of shared features and general categories. But when Levinas is describing the ethical he is attempting to give a phenomenological account of the possibility of a moral encounter in which the other does not feature as an object of comparison or contrast. In his description of the 'face' manifesting as prohibition on murder, Levinas is unearthing that dimension of experience wherein differentiation and comparison work is not possible because the distanced, generalizing stance necessary for doing such work has been disrupted and challenged. From a Levinasian perspective the Løgstrupian tendency to grasp the other person in terms of a universal - i.e., 'life' - is to cover over the resistance to being so grasped that is the defining feature of the other's ethical manifestation qua face. 
For Levinas, then, the way in which the other is given in the face-to-face experience is as a prohibition on murder - which is not a metaphysical posit about the reality of the other's status as a being who prohibits murder but rather a description of a presence experienced as a refusal to have the status of normative authority denied to it. This experienced refusal does not make murder impossible - killing is still always an option - but rather functions by making me understand that such a killing would be murder. 'Thou shalt not' communicates a demand to recognize that there is another source of normative authority outside the orbit of my own self-interest. Read in this way, the meaning conveyed by the mode of presence that Levinas names 'the face' is nothing more than a call to respect the fact that I am not the only one whose claims matter; that there are normative perspectives other than my own which call my pretentions to totality into question. Hence Levinas frequently characterizes the face as "ordering" me - a characterization that might suggest a kind of command theory but in fact is meant to capture the idea of being in the presence of something that "re-orders" me. ${ }^{25}$ Namely, a presence that shifts me from first-person to second-person concerns.

\section{Conclusion}

Throughout the Ethical Demand Løgstrup attempts to decouple the self from its vulnerabilities and desires for the goods of life by insisting that they are - or that we must think of them as - evil. I have argued that we should see Løgstrup's tendency to characterize the self as evil not as a descriptive claim about human nature but as a self-understanding constitutive of the second-person moral experience. And perhaps, in some cases, as a kind of moral heuristic helpful for tilting the balance a little bit further toward second person claims than it would otherwise be. Conceptualizing ourselves as evil or worthless is incompatible with belief in the legitimacy of our self-serving ends and thereby negates their motivational efficacy - enabling us, thereby, to value the other above ourselves. 
I have suggested that Levinas should similarly be read as engaged in the phenomenological project of describing the experience of moral claim while bracketing (at least in his philosophical texts) questions about their metaphysical justification or source. Unlike Løgstrup, however, Levinas does not describe this experience in terms of selfabnegation - i.e., in terms of the belief that dethroning the dear self requires self-attributions of worthlessness. Instead, Levinas insists that the challenge is not eradicating the claims of the self, but resisting the self's pretention to a global normative exclusivity or priority.

Once one has been exposed to the claim of the other person, a straightforward return to a prelapsarian mode of living one's first-person perspective - a complete return to the innocence of the animal or the child wherein there are no others to question one's joyous consumption of the world - is no longer possible. But first-person claims do not thereby fully drop away, even in the ethical encounter. As a result we are always shifting back and forth between the first-person and second-person perspectives - each bringing with it a fundamentally different way of living one's selfhood. For Levinas such transformational moments are possibilities built into the encounter with every other person. Such a characterization requires no metaphysical commitment to our fundamental evil nor does it require justification via appeal to an ontology of natural goodness. For Levinas there is nothing deeper than the fact of being claimed by a presence that draws me out of myself in responsibility, in language, in ethical desire. Though we can and do attempt to define and explain this fact, our attempts to do so can never offer an ultimate justification - and insofar as we attempt to do so we lose sight of the very thing we are trying to prioritize: the fact that there are others who challenge that pretention to justifiability and transform the way we live our selfhood. 


\section{References}

Andersen, Svend and Kees Van Kooten Niekerk, eds. 2008. Concern for the Other. Notre Dame: University of Notre Dame Press

Bergo, Bettina 2005. "What Is Levinas Doing? Phenomenology and the Rhetoric of an Ethical Un-Conscious," Philosophy \& Rhetoric, 38 (2): 122-144.

Bernasconi, Robert 1999. "The Third Party: Levinas on the Intersection of the Ethical and the Political," Journal of the British Society for Phenomenology 30 (1): 76-87.

Bernet, Rudolf 2002. "Levinas's Critique of Husserl," in Critchley and Bernasconi, eds. (2002, 82-99).

Christoffersen, Svein Aage 2008. "Sovereign Expressions of Life, Virtues, and Actions: A Response to MacIntyre," in Andersen and Niekerk, eds. (2008, 167-175).

Critchley, Simon 2015. The Problem With Levinas. Oxford: Oxford University Press.

Critchley, Simon and Robert Bernasconi, eds. 2002. The Cambridge Companion to Levinas, Cambridge: Cambridge University Press.

Crowell, Steven 1998. "There Is No Other: Notes on the Logical Place of a Concept," Paideuma: Mitteilung zur Kulturkunde 44: 13-29.

— 2015. "Why is Ethics First Philosophy? Levinas in Phenomenological Context," The European Journal of Philosophy 23 (3): 564-588.

Derrida, Jacques 1978. "Violence and Metaphysics: An Essay on the Thought of Emmanuel Levinas," in Writing and Difference, trans. Alan Bass, 97-192. Chicago: University of Chicago Press.

— 1995. "Tout Autre est Tout Autre," in The Gift of Death, trans. David Wills. Chicago: University of Chicago Press.

Drabinski, John E. 2001. Sensibility and Singularity: The Problem of Phenomenology in Levinas. Albany, NY: State University of New York Press.

Fink, Hans and MacIntyre, Alasdair 1997. “Introduction,” in K.E. Løgstrup (1997, xvxxxviii).

Husserl, Edmund 1999. Cartesian Meditations, trans. Dorion Cairns, Dordrecht: Kluwer Academic Publishers.

Levinas, Emmanuel 1985. Ethics and Infinity: Conversations with Philippe Nemo, trans. Richard A. Cohen, Pittsburgh: Duquesne University Press.

— 1987. Time and the Other, trans. Richard A. Cohen, Pittsburgh: Duquesne University 
Press.

— 1996. "Transcendence and Height," in Basic Philosophical Writings. Adrian Peperzak,

Simon Critchley, and Robert Bernasconi, eds., trans. Alphonso Lingis, 11- 31.

Bloomington: Indiana University Press.

--- 1999. Otherwise Than Being, or, Beyond Essence, trans. Alphonso Lingis, Pittsburgh: Duquesne University Press.

— 2007. Totality and Infinity: An Essay on Exteriority, trans. Alphonso.

Lingis, Pittsburgh: Duquesne University Press.

Løgstrup, K.E. 1997. The Ethical Demand, Hans Fink and Alasdair MacIntyre, eds., trans.

Theodor I. Jensen and Gary Puckering R. Løgstrup. Notre Dame:

University of Notre Dame Press, reprint edition.

— 2007. Beyond the Ethical Demand, trans. Susan Dew and Heidi Flegel, Notre Dame:

University of Notre Dame Press.

— 2014. Etiske Begreber og Problemer, Bjørn Rabjerg and Robert Stern, trans., eds. Aarhus: Klim. Available here:

https://ethicaldemand.files.wordpress.com/2018/07/rabjerg-etiske-begreber afterwordtranslation-final.pdf

MacIntyre, Alisdair 2008. "Human Nature and Human Dependence: What Might a Thomist Learn from Reading Løgstrup?" in Andersen and Niekerk, eds. (2008, 147166).

McMullin, Irene 2013. "Kant on Radical Evil and the Origin of Moral Responsibility," Kantian Review 18 (1): 49-72.

— 2018. Existential Flourishing: A Phenomenology of the Virtues. Cambridge: Cambridge University Press.

Mensch, James 2015. Levinas's Existential Analytic: A Commentary. Evanston: Northwestern University Press.

Morgan, Michael 2011. "How to Read Levinas: Normativity and Transcendental Philosophy," in The Cambridge Introduction to Emmanuel Levinas, 36-58. Cambridge: Cambridge University Press.

Peperzak, Adrian 1998. "Levinas’ Method," Research in Phenomenology 28: 110-25.

Perpich, Diane 1998. “A Singular Justice,” Philosophy Today 42: 59-70.

— 2008. The Ethics of Emmanuel Levinas. Stanford, Calif.: Stanford University Press. 
Rabjerg, Bjørn 2014. "Efterskrift," in K. E. Logstrup, Etiske Begreber og Problemer, Bjørn Rabjerg and Robert Stern, trans., eds. 121-47. Aarhus: Klim. Available here: https://ethicaldemand.files.wordpress.com/2018/07/rabjerg-etiske-begreber afterwordtranslation-final.pdf

— 2017. "Løgstrup's Ontological Ethics: An Analysis of Human Interdependent Existence," Res Cogitans 12 (1): 93-110.

Reinders, Hans S. 2008. "Donum or Datum? K. E. Løgstrup's Religious Account of the Gift of Life," in Andersen and Niekerk (2008, 177-206).

Sartre, Jean-Paul 1956. Being and Nothingness, trans. H. E. Barnes, New York: Simon \& Schuster Inc.

Simmons, William Paul 1999. "The Third," Philosophy and Social Criticism 25 (6): 83-104.

Smith, William H. 2011. The Phenomenology of Moral Normativity. New York: Routledge.

Stern, Robert 2019. The Radical Demand in Løgstrup's Ethics. Oxford: Oxford University Press.

Waldenfels, Bernard 2002. "Levinas and the Face of the Other," in Critchley and Bernasconi, eds. (2002, 63-81).

Wood, David 2005. "Where Levinas Went Wrong: Some Questions for my Levinasian Friends," in The Step Back: Ethics and Politics after Deconstruction, 5368. Albany, NY: State University of New York Press.

Wyschogrod, Edith 2000. The Problem of Ethical Metaphysics. New York: Fordham University Press. 
${ }^{1}$ This is not an uncontroversial claim. At times Levinas certainly speaks as if he thinks that the presence of the infinite other in some sense transcends phenomenology toward metaphysics - but for the purposes of this paper I will simply read his claims as purely phenomenological. An analysis of the degree to which Levinas is in fact a phenomenologist would take us beyond the scope of this paper. Hence throughout I will be assuming that Levinas's claims are phenomenological in tenor and arguing that Løgstrup's ought to be. For further discussion see Crowell (this volume), Crowell 2015, Morgan 2011, Smith 2011, Bergo 2005, Bernet 2002, Drabinski 2001, and Peperzak 1998.

${ }^{2}$ Sartre 1956. As Crowell puts it: "Sartre thus retains the first-person perspective but shifts the case: the Other's alterity is not given from the standpoint of the first-person nominative, but from that of the first-person accusative. It is as Me that I encounter the Other originally" $(1998,25)$.

${ }^{3}$ See, for example, Derrida 1978 and 1995, Critchley 2015, Perpich 2008, Wood 2005.

${ }^{4}$ One might argue that Løgstrup's view is less hyperbolic insofar as he stipulates that the demand cannot be understood as limitless $(1997, \S 3.2)$, while Levinas insists that it is “infinite”. But as I will argue below, the latter's reasons for this are methodological: from within the second-person stance of ethics, limits on the claim cannot appear - but in practice this infinity is always tempered and limited by the presence of the "Third" in a condition that Levinas calls justice (See Bernasconi 1999, Simmons 1999, Perpich 1998).

${ }^{5}$ See also Christoffersen 2008, 167-175.

${ }^{6}$ Similar issues arise for Levinas insofar as he characterizes ethics as an infinite obligation to the other, but one that also needs to accommodate the kind of comparison and negotiation work that necessarily arises with the presence of "the Third". See note 4 above. I read the Levinasian concepts of "ethics" and "justice" as specifying elements or dimensions of moral agency that rarely - perhaps never - exist in isolation.

${ }^{7}$ Of course, Løgstrup recognizes the danger of violence from others and hence the need for social norms, but throughout his work this propensity to violence is attributed to the unnatural evil of human selfishness, not life or nature, which is characterized as inherently good. So we may need social norms, but only to protect against human evil, which is characterized as being at odds with “life”. For Løgstrup’s comment on Nietzsche’s pessimism, see Løgstrup 2014, 20-24.

${ }^{8}$ See also Reinders 2008, 189. 
${ }^{9}$ This is not meant to suggest that the "life is a gift" component of Løgstrup's thought is to be read as the only component of his normative project: recall that the mere fact of the other's vulnerability and dependence is meant to claim the ego, on his view, much as the ego is interrupted for Levinas by a certain kind of normatively fraught presence. Indeed, it is for this reason that so many people view the two thinkers as alike. But the radicality of the other's claim is also what characterizes both thinkers: it's not simply that I feel moved to help the other who confronts me, but that I am bound infinitely; I am required to think only of the other and eradicate the self in their service. The focus of this paper is on thinking through the nature of this asymmetry and arguing that Løgstrup's position in this regard rests on an illegitimate ontology. Though Løgstrup's view could be saved from this conclusion by being read in purely phenomenological terms - as I do below - it is, as we will see, consequently vulnerable to another objection: namely, that its use of moralizing hyperbole in its phenomenological descriptions distorts the nature of the ethical encounter.

${ }^{10}$ See Fink \& MacIntyre 1997 and Stern 2019 for detailed treatment of the question of Løgstrup's theological commitments.

${ }^{11}$ See Løgstrup 1997, 66.

${ }^{12}$ One might object here that it is fine to be concerned with one's vulnerability - it simply becomes evil when you use the vulnerability of others to benefit yourself. According to this objection, the goods of life shouldn't be understood as a kind of neutral commodity for vulnerability-protection over which multiple agents are fighting; rather, the question is whether in cases where you're vulnerable to me, I should use my power to help you or use your vulnerability for my own ends. If I choose the latter, I am evil. But the power to help the other vulnerable person is often the very same power that could be used to help myself - e.g., money. But even when it's not a case where there's a general commodity like money at stake - which could potentially benefit many vulnerable persons, including myself - there will often be cases where another person is reliant on a specific skill or power I have but which I would not be "evil" to withhold out of concern for my own wellbeing. Am I evil if I refuse to provide feedback on my student's paper draft in order to get a full night's sleep? In reply, one might argue that the demand only applies when the other person is specifically reliant on me - their wellbeing is "in my hands" - and it only claims that I would be evil if I used that person's vulnerability to benefit me, not merely if I refused to help. But who counts as being "in my hands" or vulnerable specifically to me? Certainly I myself do. Further, it will be extremely difficult to know where to draw the line when it comes to others, as debates about distant others in ethics make clear. In keeping with this we might also question whether 
"evil" only refers to exploitation of that person's vulnerability in order to benefit oneself, or if, as Løgstrup's view sometimes seems to suggest, those who selfishly fail to help the vulnerable are also evil. Bringing these points together: does my mere participation in food or product supply chains that exploit the vulnerability of the distant poor count as me exploiting them, for Løgstrup? If so, that means that virtually everything I do places the wellbeing of others in my hands in a way that I am consequently abusing - a fact, again, that would seem to rule out me doing much of anything to benefit myself. Hence the worries that afflict utilitarian moral theory's insistence that we maximize the good seem to arise. Much more could be said on these difficult issues, and I refer the reader to Stern 2019, Ch. 10 for a Løgstrupian answer to them, but the point for our immediate purposes here has to do with the legitimacy of his characterization of the self in these conditions as evil.

${ }^{13}$ Section II of Totality \& Infinity is an extended reflection on the nature of the self's separation into an "I" (Levinas 2007).

${ }^{14}$ It is also not at all clear why this approach doesn't subject Løgstrup to the same objections of egoism that he levels against eudaimonism - i.e., that I engage in the SEL in order to realise my true/flourishing self. In both cases the charge can be avoided by getting clearer on the distinction between moral justification and moral motivation. In both cases, in other words, the excellence of human lives consists as least in part in acts of loving altruism - acts that cannot count as such if they are undertaken in order to achieve an excellent human life for the agent in question (McMullin 2018, especially pp. 74-77). Nevertheless, this point does not help Løgstrup with the problems about moral agency being raised in this paragraph. ${ }^{15}$ Løgstrup suggests that all talk of reciprocity in characterizing the ethical demand can be used as a way of moderating and covering it over. On the flip side, we can perhaps see that talk of radical asymmetry in characterizing the ethical demand can be used as a way of highlighting and strengthening its claim.

16 'The demand which sets reciprocity aside cannot exist in the space to which it is assigned by anti-metaphysical philosophy. Its one-sidedness presupposes a power that has given the individual their existence and world, and which at the same time presents itself as the demand's authority. This power is invisible, and as authority it is silent because it is transcendent (Løgstrup 1997, 171). See also Stern 2019, 6; 28-29; 125.

17 "In my description of the phenomena, I have only worked with comparisons and distinctions within the natural language's interpretation of existence. In short, I have stuck to phenomenological analyses and steered clear of scientific investigations" (Løgstrup 2007, 9$10)$. 
${ }^{18}$ There are interesting analogies with Kant's view on radical evil here. See McMullin 2013.

${ }^{19}$ Anthropomorphizing the demand appears to be a kind of necessary interpretive stance - a useful fiction -whereby we can understand how we can be responsible for something that's not in our control: namely, because life itself tells us we are: "[w]e can only speak about our existence and its demand in anthropomorphic terms, as we speak of a person who in opposition to us asserts that its demand can be fulfilled" (1997, 165, emphasis mine). For a discussion that tries to make sense of this "anthropomorphizing" see Stern 2019, 109-115. Questions might arise here whether Løgstrup himself slides into a command view of morality insofar as "life" is conceptualized as an agent whose authority justifies the bindingness of its claims on us. Examining this possibility would take us beyond the scope of the paper, but one potential solution would be to suggest, as Stern does, that the authority here is that of a judge, not a commander $(2019,123-4)$.

${ }^{20}$ It's not clear that Løgstrup himself would agree with this, as he seems to regularly characterize what he's doing as metaphysics: "the moment we go on to maintain that we are not the cause of our love and that we are the cause of our hate, we have gone beyond the bounds of non [or anti] metaphysical ethics" $(1997,140)$.

${ }^{21}$ Of course, questions arise here about how Levinas' "Other" can be identified with the other human being. How do we identify "this thing here" as the source of the claim? Why should we assume that only human beings are defined by this mode of presence? In other words, does genuine metaphysical neutrality of the kind I am advocating require us to remain completely agnostic about recognizing or identifying the source of the claim? These are difficult questions that cannot be fully treated here, but I will suggest that the answer is likely yes - that in its pure form the second person stance on a Levinasian account cannot be limited to the category "human being". Rather, "face" and "illeity" name only the lived experience of being called into question by a presence that resists all such categorization. Hence it may indeed be the case that a fully phenomenologically consistent Levinas would be required to say that one might feel the call in the presence of animals or the environment, say - and that limiting or locating the call solely in the human face is ultimately a task for the political realm, wherein Husserl-style arguments by analogy come into play (Husserl 1999, 'Meditation V'). Many thanks go to Robert Stern and Steve Crowell for pushing me on this point.

${ }^{22}$ Levinas 1996, 17, translation slightly altered.

${ }^{23}$ For example, Stern emphasizes that life involves "the possibility of change and renewal, so that a living thing is not defined or limited by what it was or has been" $(2019,34)$. 
${ }^{24}$ Further, Løgstrup insists that to have the authority to make the demand would require you to have a right to make it, and rights are a contractual notion that do not obtain at this level.

${ }^{25}$ Hence Levinas refers to the order "toward the face of the other" as "an ordination" that "inverses relationships and principles, reverses the order of interest" $(1999,11-12)$. 